\title{
OBÓZ NARODOWY WOBEC KONCEPCJI FEDERACYJNEJ W CZASIE II WOJNY ŚWIATOWEJ
}

Pod koniec XIX w. polska myśl polityczna była rozbita na dwa dominujące nurty ideowo-polityczne o odmiennych koncepcjach geopolitycznych Polski. Na byłych ziemiach I Rzeczypospolitej z przewagą Polaków Narodowa Demokracja chciała zbudować państwo narodowe (plan Dmowskiego, idee Jana Popławskiego)․ PPS i zwolennicy Józefa Piłsudskiego dążyli do rozbicia Rosji i związania Litwinów, Białorusinów i Ukraińców z Polską². Gdy PPS widział pokojową organizację państwa na zasadzie federacji z narodami na obszarze byłej I Rzeczypospolitej, to J. Piłsudski łączył ideę jagiellońską z prometeizmem³. Uważał, że czym innym były projekty federacyjne, a czym innym ich realizacja i szukanie poparcia wśród narodów mających w nich uczestniczyćc ${ }^{4}$. Różnice wynikały z odmiennego stopnia rozwoju świadomości narodowej Litwinów, Białorusinów i Ukraińców ${ }^{5}$. Federacja miała przyciągać inne państwa położone między Niemcami a Rosją ${ }^{6}$. Mimo zwycięstwa

\footnotetext{
1 Archiwum Akt Nowych (AAN), Komenda Główna Armii Krajowej (KG AK), Oddział VI Biuro Informacji i Propagandy (BIP), sygn. 203/VII-50, Koncepcja zwycięstwa, „Warszawski Dziennik Narodowy” (WDN), 19 III 1942, nr 5, s. 91; O rozwój myśli wszechpolskiej, „Walka”, 9 IX 1942, nr 31, s. 213; zob. T. Kulak, Jan Ludwik Popławski, Wrocław 1994, s. 164-166; R. Dmowski, Polityka polska i odbudowanie państwa, t. 2, Warszawa 1988, s. 220-221, 292, 311.

2 O federacji wschodniej Europy, „Robotnik Śląski” (RŚ), 20 XII 1919, nr 104, s. 1-2; Zagadnienie wschodniej Europy, RŚ, 3 I 1920, nr 2, s. 1; Znaczenie Polski w regulowaniu spraw Wschodu, RŚ, 30 I 1920, nr 24, s. 3; L. Moczulski, Geopolityka, potęga w czasie i przestrzeni, Warszawa 1999, s. 560-562; A. Madera, Prometeizm i polityka etniczna wobec narodów słowiańskich w poglądach i działalności Tadeusza Hołówki, w: Europa Środkowo-Wschodnia w polskiej myśli politycznej, red. M. Dymarski, J. Juchnowski, Wrocław 2004, s. 65; A. Juzwenko, Leon Wasilewski - orientacyjne kłopoty z określeniem kształtu terytorialnego państwa polskiego (1914-1918), w: Polska-Kresy - Polacy. Studia historyczne, red. S. Ciesielski, T. Kulak, K. Matwijowski, „AUW. Historia”, t. 116, nr 1636, Wrocław 1994, s. 109-113.

3 Ofederacji wschodniej Europy, RŚ, 21 XII 1919, nr 104, s. 1-2; A. Nowak, Polska i trzy Rosje. Studium polityki wschodniej Józefa Pitsudskiego (do kwietnia 1920 roku), Kraków 2015, s. 575-576, 581-585; zob. Ruch prometejski $i$ walka o przebudowę Europy Wschodniej (1918-1940), red. M. Kornat, Warszawa 2012.

4 P. Wandycz, O federalizmie i emigracji. Reminiscencje o rzeczach istotnych i błahych, Lublin 2003, s. 13-14, 22-23.

5 A. Marszałek, Europejska idea integracji międzynarodowej w perspektywie historycznej, Toruń 2008, s. 176.

6 Zakład Narodowy im. Ossolińskich (ZNO), Papiery Kazimierza Sosnkowskiego (PKS), sygn. 16501/III/t.1, Sosnkowski do marszałka Piłsudskiego, Warszawa 3 V 1920, s. 7; Sosnkowski do marszałka Pitsudskiego, Warszawa 12 V 1920, s. 12-13; Sosnkowski do marszałka Pitsudskiego, Warszawa 14 V 1920, s. 20; sygn. 16501/III/t.2, Sosnkowski do premiera Skulskiego, Warszawa 4 V 1920, s. 20-21; Sosnkowski do generała Rozwadowskiego, Warszawa 4 V 1920, s. 22; Sosnkowski o krajach baltyckich i Rumunii dla bezpieczeństwa Polski, s. 78-80; PKS, sygn. 16502/III, Sosnkowski o polityce wschodniej marszałka Piłsudskiego, s. 2-6; zob. M. Pestkowska, Kazimierz Sosnkowski, Wrocław 1995, s. 55.
} 
nad Rosją Radziecką (I920) Polska była za słaba do zorganizowania federacji. Polska opinia publiczna nie podzielała zapału do niej, zadowalając się niepodległością. Także Litwini, Ukraińcy i Białorusini nie poparli polskich planów wspólnego państwa7. Nie akceptowały ich sąsiednie i zachodnie mocarstwa oraz Czechosłowacja ${ }^{8}$.

Polskie bezpieczeństwo w okresie międzywojennym SN widziało w antyniemieckich sojuszach z Francją i Wielką Brytanią oraz Czechosłowacjąą. Polską misją dziejową była organizacja państw między Niemcami i ZSRR z dominacją Polski jako państwem narodowym, a nie federacyjnym ${ }^{\mathrm{IO}}$. Po I wojnie światowej pozytywnym zjawiskiem geopolitycznym dla SN było dochodzenie do władzy ruchów narodowych w Europie ${ }^{\text {II }}$ Zakładało ono antyniemiecką współpracę z ZSRR ${ }^{\text {I2 }}$. Klęska w 1939 r. wynikała z braku przygotowania Polski do wojny i nieudolnego jej prowadzenia oraz braku asymilacji mniejszości narodowych i rozbicia klasowego narodu ${ }^{\mathrm{I} 3}$. Sprzeciwiało się idei Richarda Coudenhove-Kalergiego i planowi Aristida Brianda, ponieważ chcieli budować unię europejską na hegemonii francusko-niemieckiej, dopuszczając rewizję wersalskich granic ${ }^{14}$. Polscy nacjonaliści określali ideę paneuropejską jako ,propagandę masońską i germanofilską”, choć Watykan popierał federację Europy bez ZSRR ${ }^{15}$.

W odezwie do kraju premier generał Władysław Sikorski zapowiedział I8 grudnia I939 r. nowy ład polityczny między Bałtykiem, Morzem Czarnym i Adriatykiem w postaci „,solidarnego zespołu państw słowiańskich", aby powstrzymać Niemcy i oddzielić je od Rosji ${ }^{16}$. Obok federacji środkowoeuropejskiej powstałyby skandynawska, bałkańska i łacińska. Od I940 r. stało się to oficjalną doktryną MSZ ${ }^{17}$. Dwustopniowa integracja Europy zapobiegłaby hegemonii mocarstw. Europejscy federaliści zakładali jednostopniowy jej model ${ }^{18}$. Kwestia pokoju i bezpieczeństwa oraz położenie geopolityczne Polski determinowały działania rządu

\footnotetext{
A. Marszałek, op. cit., s. 179-180.

8 ZNO, sygn. 189165, M. Sokolnicki, Polacy wobec zagadnień międzynarodowych, „Sprawy Obce”, 3/1930, s. 491; K. Lewandowski, Sprawa ukrainska w polityce zagranicznej Czechosłowacji w latach 1918-1932, Wrocław 1974, s. 182.

9 M. Śliwa, Polska myśl polityczna w I połowie XX wieku, Wrocław 1993, s. 167-168.

10 J. Waskan, Koncepcje społeczno-polityczne Romana Rybarskiego, Toruń 1991, s. 109.

11 K. Kawalec, Narodowa Demokracja wobec faszyzmu 1922-1939, Warszawa 1989, s. 154.

12 M. Śliwa, op. cit., s. 169.

13 „Walka”, 29 IX 1943, nr 37, s. 1-2; AAN, SN, sygn. 206/18, Uwagi w sprawie wychowania narodowego, broszura Zarządu Stołecznego SN, s. 78.

14 J. Chodorowski, Unia Paneuropejska, „Wolna Polska”, 1999, nr 4/154; J. Tombiński, Poczatki ruchu paneuropejskiego w Polsce, w: Z dziejów prób integracji europejskiej od średniowiecza do współczesności, red. M. Pułaski, Kraków 1995, s. 87-89.

15 ZNO, sygn. 209944, A. Romer, Paneuropa? Między młotem amerykańskim a rosyjskim, „Nasza Przyszłość”, 3/1930, s. 98-101; PKS, sygn. 16543/II/t.1, R. Rybarski, Uwagi o przyszłym układzie prawno-politycznym Europy Środkowej i Wschodniej, Warszawa 5 XI 1940, s. 21-31, (Stosunki międzynarodowe powinny opierać się na współpracy państw narodowych i na sojuszach państw o zbieżnych interesach. Paneuropę uznał za ideę pangermańską w celu przywrócenia hegemonii Niemiec na gruzach systemu wersalskiego. Federalistyczne plany europejskie i polskie uważał za urojenia).

16 Odezwa Rządu z dnia 18 XII 1939 r. do ogólu spoleczeństwa w kraju, w: Rzeczpospolita Polska czasu wojny. Dziennik Ustaw i Monitor Polski 1939-1945, Warszawa 1999, Monitor Polski, Angers 19 XII 1939 r., rok XXII, nr 277-284.

17 E. Ponczek, Idea federacji europejskiej w polskiej myśli politycznej (1939-1945), w: Proces integracji Polski z Unia Europejska, red. P. Dobrowolski, K. Stolarczyk, Katowice 2001, s. 211-212.

18 F. Gross, Federacje i konfederacje europejskie: rodowód i wizje, Warszawa 1994, s. 6.
} 
w zakresie nowego ładu w Europie Środkowej. Przeciwstawiał się podziałowi Europy na strefy wpływów, dominacji mocarstw, czy ich hegemonii w Europie i na świecie ${ }^{19}$. Koncepcją federacji środkowoeuropejskiej zajmowało się Biuro Celów Wojny, a od I942 r. Ministerstwo Prac Kongresowych ${ }^{20}$. W latach I940-I942 rządy Polski i Czechosłowacji zawarły umowy o związku, otwartym na kraje Europy Środkowej ${ }^{21}$. Po zerwaniu polsko-radzieckich stosunków dyplomatycznych w I943 r. Czechosłowacja porzuciła konfederację z Polską, której sprzeciwiała się ZSRR ${ }^{22}$. W grudniu I943 r. zawarła z ZSRR układ o przyjaźni i wzajemnej pomocy, przekreślając polską koncepcję federacyjną. Pod wpływem ZSRR zachodnie mocarstwa zaniechały planów federalizacji Europy ${ }^{23}$.

Budowa z Czechosłowacją nowego ładu w Europie Środkowej wywołała dyskusję w kraju. Zagrożenie Polski ze strony Niemiec i ZSRR zamierzano neutralizować powiększeniem terytorium, nowym przebiegiem granic ${ }^{24}$, realizacją federacji regionalnych między Bałtykiem, Adriatykiem i Morzem Czarnym (dalej ABC), powołując się na polską tradycję unijną ${ }^{25}$. Obóz narodowy wysunął ideę imperialną jako konkurencyjną wobec idei federacyjnej. SN uważało, że od wojen napoleońskich w Europie dominowała idea narodowa, a federacyjna stała się anachroniczna. Realizowana po I wojnie światowej wobec narodów wschodnich naraziła Polskę na utratę niepodległości w wojnie z Rosją Radziecką. Do tego PPS i piłsudczycy wspierali tworzenie państw narodowych Białorusinów, Litwinów i Ukraińców na polskim obszarze cywilizacyjnym (I Rzeczpospolita) ${ }^{26}$. Swoją polityką wschodnią J. Piłsudski przekreślił program inkorporacyjny Romana Dmowskiego ${ }^{27}$. Z tego powodu

19 E. Ponczek, Polska myśl o pokoju w latach drugiej wojny światowej (1939-1945), Łódź 1999, s. 127.

20 Dzienniki Czynności Prezydenta RP Władysława Raczkiewicza 1939-1947, t. 1 (1939-1942), red. J. Piotrowski, Wrocław 2004, s. 300; B. Pasierb, Marian Seyda i resort planowania politycznego na obczyźnie, 1939-1944, w: Polska-Kresy-Polacy, s. 259-263.

21 M. Pułaski, Edvard Beneš o projektach konfederacji czechosłowacko-polskiej w latach II wojny światowej, w: Z dziejów Europy Środkowej w XX wieku, Kraków 1997, red. M. Pułaski, s. 153-169; J.R. Sielezin, Idea federacji polsko-czechosłowackiej jako element gry politycznej w latach 1939-1943, w: Europa Środkowo-Wschodnia w polskiej myśli politycznej, s. 147-149; J. Němeček, Czechosłowacko-polskie koncepcje federacyjne w okresie II wojny światowej, w: Europa unii i federacji. Idea jedności narodów i państw od średniowiecza do czasów wspótczesnych, red. K. Ślusarek, Kraków 2004, s. 348-349; M.K. Kamiński, Edvard Beneš kontra generał Władysław Sikorski. Polityka władz czechosłowackich na emigracji wobec rządu polskiego na uchodźstwie 1939-1943, Warszawa 2005, s. 74-76.

22 H. Bartoszewicz, Związek Sowiecki wobec federacyjnych koncepcji w Europie Środkowo-Wschodniej 1941-1948, w: Z dziejów prób integracji europejskiej, s. 139-142.

23 L. Gardner, Strefy wptywów. Wielkie mocarstwa i podziat Europy od Monachium do Jalty, Warszawa 1999, s. 185-187; A. Kastory, Winston Spencer Churchill, Wrocław 2004, s. 258.

24 AAN, KG AK, BIP, sygn. 203/VII-67, Problem przyszłych granic Polski. Materiat dla prelegentów propagandowych, 1942, s. 11-21; R. Wapiński, Historia polskiej myśli politycznej XIX i XX wieku, Gdańsk 1997, s. 258-259; B. Pasierb, Polskie prace przygotowawcze do traktatu pokojowego z Niemcami (1939-1945), w: A. Czubiński, Druga wojna światowa i jej nastęstwa, Poznań 1996, s. 205-215.

25 AAN, sygn. 202/II-15, Delegatura Rządu na Kraj (DR), Departament Spraw Wewnętrznych (DSW), Stosunki polsko-rosyjskie, 1943, s. 24; zob. J. Sadowski, Polscy federaliści i konfederaliści w czasie II wojny światowej, cz. 2, „Studia Europejskie”, 4/2005, s. 25-26.

26 AAN, DR, Departament Informacji i Prasy (DIP), sygn. 202/III-87, Cywilizacja polsko-chrześcijańska wobec cywilizacji zachodnioeuropejskiej, „Sprawy Narodu”, lipiec 1943, nr 1, s. 98; sygn. 202/III-81, Dwóch wojewodów, „Młoda Polska”, 20 I 1944, nr 2, s. 11; zob. E. Ponczek, Dyskurs o kulturze w polskiej myśli politycznej (19391945), Toruń 2006, s. 16; (W czasie II wojny światowej członkowie Stronnictwa Narodowego, Obozu Narodowo-Radykalnego „ABC” i Ruchu Narodowo-Radykalnego „Falanga” utworzyli kilka grup podziemnych, które należały do szeroko rozumianego obozu narodowego).

27 AAN, DR, DIP, sygn. 202/III-80/t. 1, Przed dwudziestu laty, WDN, 6 III 1943, nr 10, s. 134. 
II Rzeczpospolita była słaba. Utraciła Gdańsk, Prusy Wschodnie, Śląsk Cieszyński. Polscy federaliści kontynuowali politykę Wiednia i Berlina (Mitteleuropa) ${ }^{28}$, które skłócały narody wschodnie z Polakami na polskim obszarze cywilizacyjnym. Dążyły do powstania w Europie Wschodniej słabych i wrogich państw wobec Polski i Rosji. Program polski R. Dmowskiego dążył do odbudowy Polski na jej historycznych ziemiach i do osłabiania Niemiec. Gdyby J. Piłsudski wcielił ziemie litewskie, białoruskie i ukraińskie do Polski, a rządy piłsudczyków asymilowały mniejszości narodowe, to nie byłoby klęski w I939 r. i mordowania Polaków przez mniejszości narodowe na polskiej ziemi w sojuszu z Niemcami lub ZSRR ${ }^{29}$.

Ideę jagiellońską SN utożsamiało z ideą Wielkiej Polski od Odry i Nysy Łużyckiej po Dniepr $^{30}$, a nie $\mathrm{z}$ federacją $\mathrm{z}$ narodami wschodnimi. Na międzymorzu bałtycko-czarnomorskim uniemożliwiłaby ona realizację Mitteleuropy i Lebensraumu oraz zlikwidowała radzieckie republiki. Na byłym obszarze I Rzeczypospolitej nie mogły istnieć inne państwa poza polskim. Litwini otrzymaliby autonomię narodowo-kulturalną w ramach Polski ${ }^{31}$. Naród białoruski znalazłby się w jej granicach z powodu słabej świadomości narodowej ${ }^{22}$. Ukraińcy nie posiadali państwowotwórczych zdolności ${ }^{33}$, a Rusini obok Białorusinów asymilowali się z narodem polskim. Unia z ich państwami zagrażałaby niepodległości Polski (sojusz z Niemcami, ZSRR) i jej integralności terytorialnej (żądały granicy z Polską co najmniej na linii Curzona) ${ }^{34}$. Politycznie, etnicznie, kulturowo i organizacyjnie nie były przygotowane na utrzymanie niezależności politycznej i gospodarczej swoich państw. Niemcy i Rosjanie nie dali im państwowości (komisariaty, radzieckie republiki). Także Polska nie powinna narażać swojego potencjału i niepodległości wobec ZSRR w celu ich tworzenia. Po Stalingradzie

28 AAN, SN, sygn. 206/3, Co znaczy być narodowcem, broszura SN, s. 37.

29 Zręby frontu ludowego w Polsce, ,Walka”, 30 III 1944, nr 13, s. 9-11; Dwa fronty, „Walka”, 4 V 1944, nr 16, s. 6-8; Tak zwany głos ludu, ,Walka”, 29 VI 1944, nr 24, s. 1-2; Fermenty, „Walka”, 14 VII 1944, nr 26, s. 3; AAN, DR, DSW, sygn. 202/II-22, Sprawozdanie sytuacyjne nr 1 z życia polskich stronnictw politycznych Polski podziemnej, SN, I kwartał 1944, s. 197.

30 Nie niszczyć dzieła Jagiellonów, „Walka”, 1 VIII 1941, nr 31, s. 1; Gdzie jest Polska na wschodzie, „Walka”, 12 IX 1941, nr 36, s. 1; Korektura granicy wschodniej, „Walka”, 24 X 1941, nr 42, s. 2-3; DR, DIP, sygn. 202/III-80/t.1, Usunać fatszywe drogowskazy; Na manowcach federacyjnych, WDN, 27 II 1943, nr 9, s. 117-118; ZNO, Papiery Klaudiusz Hrabyka (PKH), sygn. 16320/II, K. Hrabyk, Problem rosyjski w polityce endecji, Warszawa 1971 (maszynopis), s. 98-99.

31 Litwa, „Walka”, 10 X 1941, nr 40, s. 2-3; sygn. 1031/3, Litwo, Ojczyzno moja ..., „Walka”, 30 IX 1942, nr 37 , s. 2.

32 Na śmietniku wschodniego ładu brzęczy białoruska mucha, „Walka”, 11 III 1942, nr 9, s. 4; Dwie tęsknoty, „Walka”, 7 X 1942, nr 38, s. 1-2.

33 Sprawa ukraińska, „Walka”, 4 VIII 1943, nr 29, s. 9-12; SN, sygn. 206/2, Stanowisko Stronnictwa Narodowego w sprawie ukraińskiej, X 1943, s. 1-1a; AAN, DR, DIP, sygn. 202/III-80/t.2, Kijowszczyzna - ukrainna ziemia Rzeczypospolitej, WDN, 15 V 1943, nr 19, s. 306; Historyczne tło kwestii ukraińskiej, WDN, 26 VI 1943, nr 22, s. 412; sygn. 202/III-88, Wczoraj, dzisiaj, jutro zagadnienia ukraińskiego w Polsce, „Służba Informacyjna Walki”, 1944, s. 85; (Rusini wywodzili się tradycji księstw ruskich zajętych przez Litwę i Polskę. Żyli w zgodzie z Litwinami i Polakami w I Rzeczypospolitej. Ukraińcy wywodzili się od Kozaków z Siczy i Zaporoża, którzy wywołali bunt pod wodzą Bohdana Chmielnickiego. Od XVII w. wspierała ich Rosja, od XIX w. Austria, a od I wojny światowej Niemcy przeciwko państwu i narodowi polskiemu. Separatyzm ukraiński podburzał Rusinów do tworzenia z Ukraińcami państwa na ziemiach polskich).

34 Wilno i Ziemia Wileńska, „Myśl Polska”, 20 II 1942, nr 19, s. 333-334; Litwa, „Myśl Polska”, 5 IV 1942 , nr 21, s. 362-363, (Wolna Litwa to hasło każdego Polaka, ale musiała związać się z Polską); AAN, SN, sygn. 206/18, Wrzesień 1939 r., s. 100; sygn. 202/III-80/t.2, Granica pólnocno-wschodnia Polski, WDN, 12 VI 1943, nr 21, s. 376 . 
W I943 r. w imię porozumienia z Moskwą SN było gotowe wspólnie zwalczać ich dążenia niepodległościowe za poszanowanie suwerenności i granic Polski35.

SN sprzeciwiało się federacjom lub federacji w Europie Środkowej ${ }^{36}$. Zdegradowałyby one znaczenie Polski wobec małych narodów. Na obszarze Polski Trzech Mórz Wielka Polska jednoczyłaby państwa narodowe między Niemcami i ZSRR ${ }^{37}$. Na arenie międzynarodowej socjalizm i komunizm propagował ponadnarodową integrację $\mathrm{z}$ hasłami międzynarodowego braterstwa proletariatu, a SN było za chrześcijańskim blokiem państw narodowych ${ }^{38}$. Federacje niszczyłyby je na rzecz instytucji ponadnarodowych, w których decydowałyby antynarodowe międzynarodówki ${ }^{39}$. SN nie godziło się na dzielenie obszaru ABC na unię jugosłowiańsko-grecką i konfederację polsko-czechosłowacką. Przeciwstawiało masońskiej i proradzieckiej Czechosłowacji prezydenta Edvarda Beneša związek z narodowymi Czechami. Musiały się zgodzić na pozostanie Zaolzia przy Polsce i Rusi Podkarpackiej przy Węgrzech (granica polsko-węgierska). Za politykę zagraniczną i wojskową odpowiadałaby Polska, a Czesi za gospodarczą, ponieważ ulegali mocarstwom kosztem swojej wolności. Za Ruś Podkarpacką dostaliby Łużyce. Granica węgiersko-słowacka biegłaby według zasady etnicznej. Przy Węgrzech zostałby Siedmiogród ${ }^{40}$.

W okupowanym kraju ideę federacyjną popierały ugrupowania demokratyczne, piłsudczykowskie, socjalistyczne, syndykalistyczne i ludowcy, dla których obóz narodowy był przeciwnikiem ideowo-politycznym. Demokracja była nie do przyjęcia dla SN, stąd jej sprzeciw wobec takiego ustroju konfederacji polsko-czechosłowackiej. W interesie Wielkiej Brytanii były demokratyczne federacje regionalne w celu jej powojennej hegemonii na kontynencie.

\footnotetext{
35 Bitwy polityczne, „Walka”, 18 XI 1943, nr 44, s. 1-3.
}

36 Legenda narodu polskiego, ,Walka”, 11 II 1942, nr 5, s. 1; Los w naszych rękach, „Walka”, 22 IV 1942, nr 14, s. 1; Wyzyskiwanie i nadużywanie uczciwości, „Walka”, 20 V 1942, nr 18, s. 1; Europa Środkowa ośrodkiem pokoju, „Myśl Polska”, 20 V 1942, nr 24, s. 401-403, (Powinna być konfederacją państw narodowych Polski, Czechosłowacji, Węgier i Rumunii).

37 Polska Trzech Mórz, „Walka”, 19 IX 1941, nr 37, s. 2-3; Zadania Polski Trzech Mórz, „Walka”, 25 XII 1942 , nr 49, s. 2-3; AAN, DR, DIP, sygn. 202/III-80/t.1, Ku Polsce Trzech Mórz, „Polak”, 29 X 1942, nr 4, s. 7; O przebudowę Europy, „Myśl Polska”, 15 III 1942, nr 20, s. 346-347; M.E. Rojek, Osobowość polityczna Polski po tej wojnie „Myśl Polska”, 1 V 1942, nr 22-23, s. 378-380, (Związek Polski, Czechosłowacji i Litwy).

38 AAN, SN, sygn. 206/1, Instrukcja dla propagandzistów w środowisku robotniczym, 1943, 17-22; F. Gross, op. cit., s. 81-83, (Stanisław Strzetelski (Federation in its Place, „New Europe”, styczeń 1942) uważał, że po wojnie federacja mogła być użytecznym instrumentem w przezwyciężeniu wielu politycznych i gospodarczych problemów. Nie zgadzał się z doktryną federalizmu, która za pomocą systemu federacyjnego miałaby rozwiązać wszystkie dotychczasowe problemy Polski i Europy. Nie rozwiązywał on problemu samostanowienia narodów i powszechnego bezpieczeństwa. Nie był w stanie zastąpić kolejnej powojennej Ligi Narodów. Sfederowane narody Europy Środkowej mogłyby wytworzyć przeciwwagę dla imperializmu Niemiec i Rosji, jeśli powiązania w ramach związku byłyby na tyle silne, aby uformować sprawnie działającą jednolitą strukturę. Takie powiązanie mogło wypływać ze wspólnoty duchowej lub powstać mechanicznie. Powiązanie mechaniczne prowadziło do centralizacji władzy i administracji. W przypadku powiązania duchowego poczucie narodowego interesu zostałoby podporządkowane patriotyzmowi szerszej federalnej ojczyzny. Twierdził, że konfederacja narodów Europy Środkowej-zwłaszcza w obecnej epoce totalnej wojny - mogłaby się stać efektywnym i niezależnym instrumentem pod warunkiem, że zmieniłaby się w jednolicie zarządzane imperium).

39 Niezdrowe wspólnoty, ,Walka”, 29 VII 1942, nr 28, s. 1.

40 Polska-Czechy, „Walka”, 25 X 1940, nr 29, s. 6; Unia polsko-czeska, „Walka”, 15 XI 1940, nr 32, s. 3; Zwiąek polsko-czeski, „Walka”, 1 XI 1941, nr 43, s. 2-3; Zwiazek polsko-czeski, „Walka”, 24 VI 1942, nr 23, s. 1-2; Co będzie z unia polsko-czeską?, „Walka”, 25 VIII 1943, nr 32, s. 4-5; AAN, KG AK, BIP, sygn. 203/VII-48, Nasze stanowisko. Na marginesie konfederacji polsko-czechosłowackiej, WDN, 15 II 1942, nr 2, s. 115-116; Związek Polski i Czechosłowacji, „Myśl Polska”, 20 II 1942, nr 19, s. 328-330, (Związek Polski, Czechosłowacji i Węgier zrealizowałby ideę jagiellońską). 
Byłyby za słabe, aby samodzielnie przeciwstawić się Niemcom i ZSRR. W stosunkach wewnętrznych federacje zrównywały prawnie mniejszości narodowe z narodem panującym, wobec którego były często nielojalne. Powojenna Polska byłaby państwem narodowym i katolickim, a nie narodowościowym, bez Niemców i Żydów oraz reform społecznych odbierających własność Polakom. Prawa dla mniejszości słowiańskich i litewskiej były zależne od ich stosunku do Polaków w czasie wojny. Za ich antypolskie zbrodnie czekała je kara, a mniejszość ukraińską wysiedlenie w głąb Polski lub do ZSRR za Polaków. Jedynie Polska Trzech Mórz (Wielka Polska i jej blok państw na obszarze ABC) była w stanie przeciwstawić się niemieckiemu i radzieckiemu imperializmowi, gwarantować pokój w Europie oraz dać wolność i rozwój państwom środkowoeuropejskim. Niemcy zostałyby okrojone do Renu przez Francję, Szlezwik i Holsztyn zajęłaby Dania, ziemie do Odry i Nysy Łużyckiej z Rugią, Uznamem i Wolinem - Polska, a Saksonię po Chemnitz - Czechy. Powstałoby państwo serbołużyckie. Wirtembergia, Badenia, Bawaria i Austria utworzyłyby państwo katolickie ${ }^{41}$. Na wschodzie Polska graniczyłaby z Rosją niezależnie od jej ustroju. Jej granice bezpieczeństwa SN określało między Szczecinem, Triestem, Odessą i Pskowem, co pokrywało się z obszarem Polski Trzech Mórz. Pokojowa organizacja czworoboku bezpieczeństwa była dziejową i życiową koniecznością Polski. Znalazłyby się w nim bratnie narody zagrożone przez Niemcy i ZSRR od Czech po Serbię ${ }^{42}$.

Wielka Polska nie byłaby państwem imperialnym, czyli narodowościowym. Jej odbudowa w historycznych granicach nie była imperializmem, a odbiorem polskich ziem Niemcom i ZSRR ${ }^{43}$. Dla SN ważniejsza była idea narodowa, państwo narodowe i granice niż federacja Europy Środkowej. Federacje regionalne były anachronizmem w świecie, w którym dominowały państwa narodowe i narody dążące do wolności. Mogły się one łączyć w bloki czy unie bez naruszania niezależności państwowej. Idea federacyjna dzieliła historyczne narody i terytoria państw w imię praw mniejszości i praw człowieka. Federacja Europy groziła hegemonią mocarstw (Stany Zjednoczone Europy, Rada Europy Churchilla z I943, Paneuropa, Związek Radzieckich Republik Europy) ${ }^{44}$.

${ }^{41}$ Granice Polski, „Walka”, 15 XI 1940, nr 32, s. 1; Odra-Nysa Lużycka, „Walka”, 26 IX 1941, nr 38, s. 2-3; AAN, SN, sygn. 206/18, Wrzesień 1939 r., s. 95-97; KG AK, BIP, sygn. 202/VII-32, Wielka polityka czy pieniacka zaściankowość, „Walka”, 10 XII 1942, nr 47, s. 15; Straż nad Odra, „Młoda Polska”, 10 V 1943, nr 9, s. 33; DR, DIP, sygn. 202/III-80/t.1, Idea w poniewierce, „Młoda Polska”, 20 II 1943, nr 4, s. 107; Testament Chrobrego, „Młoda Polska”, 24 IV 1943, nr 8, s. 246.

42 Czworobok bezpieczeństwa, „Walka”, 7 XI 1941, nr 44, s. 1-2; SN, sygn. 206/18, „Prawdzic”, Zagadnienie strefy środkowej, 1944, s. 103-110, (Nie zgadzał się na rozbijanie obszaru ABC na blok północny i południowy); Strefa środkowa, „Myśl Polska”, 1 XII 1943, nr 59, s. 834-835, (Strefa Środkowa była przeciwieństwem Mitteleuropy i pokrywała się z nieco mniej zdefiniowanym pojęciem Europa Środkowa. Była geograficzną całością, stanowiąc polityczną i kulturalną łączność. Tu powstały trzy wielkie dynastie: niemieckich Habsburgów, polskich Jagiellonów i węgierskich Andegawenów. Ich cechą była integracja na zasadzie dobrowolności, co Polska zachowała do jej rozbiorów. Środkowoeuropejskie unie powstrzymałyby agresje Niemiec i Rosji. W ramach Strefy Środkowej powinny powstać bloki północny (Polska) i południowy (Jugosławia), które byłyby złączone unią lub luźną konfederacją o charakterze gospodarczym i wojskowym. Nie mogły one izolować żadnego państwa Strefy, być wrogie Włochom i Turcji oraz agresywne wobec Niemiec i ZSRR. Na arenie międzynarodowej kierowałyby się solidarnością, a spory rozwiązywały między sobą na zasadzie kompromisu).

43 Imperium narodu polskiego, „Walka”, 29 VIII 1941, nr 34, s. 2-3; Tylko wielka i silna Polska, „Walka”, 5 IX 1941, nr 35, s. 1; Polska idea narodowa, „Walka”, 17 VI 1942, nr 22, s. 1; Tam gdzie była Polska, „Walka”, 18 VIII 1943, nr 31, s. 3-6; DR, DIP, sygn. 202/III-80/t.2, Mały nacjonalizm i abstrakcyjny katolicyzm, „Młoda Polska”, 29 V 1943, nr 10, s. 364.

44 AAN, Polskie Ugrupowania w Wielkiej Brytanii (PUWB), sygn. 220/t.27, List otwarty do Antoniego Stonimskiego, Szkocja, 1 III 1941, podpisał D., s. 1; Stany Zjednoczone Europy, „Walka”, 26 VII 1940, nr 16, s. 4; Europa 
Na ideę federacyjną rządu Narodowo-Ludowa Organizacja Wojskowa odpowiedziała Państwem Zachodniosłowiańskim ${ }^{45}$. Koncepcja Karola Stojanowskiego była syntezą programów występujących w polskiej myśli politycznej na przestrzeni wieków, którą dostosował do aktualnej sytuacji międzynarodowej. Losy wojenne, regionalne sąsiedztwo, wspólna historia, położenie geopolityczne, religia katolicka (Polacy, Litwini, Słowacy, Czesi, Serbołużyczanie, Węgrzy, Chorwaci, Słoweńcy, co nie eliminowało prawosławnych Serbów, Bułgarów i Rumunów, ale lepiej gdyby przeszli na katolicyzm, Łotyszy i Albańczyków) jednoczyłyby narody środkowoeuropejskie na obszarze ABC ${ }^{46}$. Niemiecka okupacja wzmocniła ich świadomość i wspólnotę narodową. Państwo Zachodniosłowiańskie byłoby związkiem ich państw z ograniczoną suwerennością do ściśle określonych wspólnych zadań w zakresie obrony, spraw zagranicznych i gospodarczych bez struktur ponadnarodowych. Państwa członkowskie dysponowałyby prawem rozwoju narodowego, kulturalnego i społecznego. Tylko w tej formie terytorialnej i ideowej mogła Polska obronić siebie i Europę Środkową przed Niemcami i ZSRR. NLOW sprzeciwiała się federacji Europy"7, ponieważ rządziłyby w niej mocarstwa i ideologiczne międzynarodówki. Zaś idea regionalnej federacji w Europie Środkowej była niemieckim planem w celu organizacji małych narodów i państw wokół Niemiec. Ten plan przejął J. Piłsudski i jego zwolennicy w celu rozbicia Rosji, co uniemożliwiło R. Dmowskiemu realizację polskiego planu inkorporacyjnego.

NLOW irytowało, że w czasie II wojny światowej ponownie wróciły federacyjne „fałszywe drogowskazy"48. Umowy polsko-czechosłowacka i jugosłowiańsko-grecka z I942 r. traktowano jako początek Państwa Zachodniosłowiańskiego. Polska wzięłaby na siebie organizację Europy Środkowej z racji tradycji unijnych i wolnościowych. Jej walka z hegemonią Niemiec i ZSRR w Europie, wojenny wkład, brak rządu kolaboracyjnego i sprzeciw wobec stref wpływów Wielkiej Trójki dawał jej prawo do kierowniczej roli w Europie Środkowej jako „starszego brata”, a nie hegemona. Konfederacja polsko-czechosłowacka i unia jugosłowiańsko-grecka nie mogły integrować Europy Środkowej49. Realizowały brytyjski interes z prawami dla mniejszości narodowych i demokratycznym ustrojem. Polska miała być narodowa, katolicka i autorytarna, a mniejszości narodowe nie posiadałyby równych praw z narodem polskim. Umowy z 1942 r. dzieliły obszar ABC, przez co byłby zależny od zachodnich mocarstw, aby obronić się przed Niemcami i ZSRR. Wywoływały one spory

\footnotetext{
jako forteca niemiecka, „Walka”, 29 XI 1940, nr 34, s. 2; Europejskie czy polskie rozwiazanie?, „Walka”, 18 VIII 1943, nr 31, s. 7.

45 Biblioteka Narodowa (BN), mf. 54706, J. Kaliski, Państwo Zachodniosłowiańskie, Warszawa 1942, s. 3-32; AAN, DR, DIP, sygn. 202/III-115/t.1, Państwo Zachodniostowiańskie, „Polski Informator Narodowy”, 25 XI 1942, s. 4-5; zob. P. Eberhardt, Polska i jej granice. Z historii polskiej geografii politycznej, Lublin 2004, s. 181-182; P. Grabowiec, Od partykularyzmu do uniwersalizmu. Polskie koncepcje międzynarodowej integracji politycznej w latach 1939-1945. Zarys problematyki, w: Federalizm, teoria i koncepcje, red. W. Bokajło, Wrocław 1998, s. 216226.

46 BN, mf. 54706, J. Kaliski, Państwo Zachodniosłowiańskie, s. 3-6.

47 E. Ponczek, Polska myśl o pokoju ..., s. 129.

48 „1723” (Kazimierz Próchnik), Usunąć fałszywe drogowskazy, „Głos”, 27 II 1943, s. 3; idem, Na manowcach federacyjnych, „Głos”, 27 II 1943, s. 4; „Baryka” (Tadeusz Przeciszewski), Przed dwudziestu laty, „Głos”, 6 III 1943 , S. 3.

49 „Prus”, Nasze stanowisko. Na marginesie konfederacji polsko-czeskiej, „Głos”, 18 II 1942, nr 14, s. 4-5; „1723”, Na manowcach federacyjnych, „Głos”, 27 II 1943, s. 4; AAN, KG AK, BIP, sygn. 203/VII-66, Dyspozycja referatu o sytuacji wewnętrzno-politycznej na kurs informacyjny dla kandydatów na stanowiska w BIP-ach polowych, $362 / 5 \mathrm{P}, \mathrm{nr} 171 / 43$, s. 50.
} 
między Słowakami i Czechami oraz Chorwatami i Bułgarami a Serbami, przez co ich wspólne państwa były słabe i narażone na wrogą ingerencję z zewnątrz. Państwo Zachodniosłowiańskie nie antagonizowałoby, tylko broniłoby Słowian. W celu utrzymania pokoju współpracowałoby ściśle z blokiem skandynawskim i łacińskim ${ }^{50}$. Dla jego realizacji Polska posiadałaby granice na Odrze i Nysie Łużyckiej, wybrzeże bałtyckie od Rugii po Prusy Wschodnie, ryską (a nawet z I772 r.) ) $^{\text {II }}$. Granice na obszarze ABC zostałyby wykreślane na zasadzie etnicznej w celu eliminacji problemów narodowościowych i ingerencji mocarstw ${ }^{52}$. Słowacja byłaby niepodległa, ale ziemie z mniejszością węgierską oddałaby Węgrom, a Rumunia Siedmiogród. Zaolzie zostałoby przy Polsce. Czesi i Słowacy mogli tworzyć wspólne państwo, ale bez centralizmu i czechosłowakizmu. Połączona unią z narodowymi, a nie beneszowskimi Czechami Polska odpowiadałaby w Państwie Zachodniosłowiańskim za politykę zagraniczną i wojskową, a Czechy gospodarczą. NLOW była za państwem łużyckim między Odrą a Łabą ${ }^{53}$. Litwa byłaby częścią Polski za jej sojusze z ZSRR i Niemcami ${ }^{54}$. Białorusini nie tworzyli jeszcze narodu ${ }^{55}$, a Ukraińcy nie dorośli do stworzenia państwa.

Za podstawę jedności Europy Środkowej „Ojczyzna” brała blok polsko-czesko-słowacki ${ }^{5}$. Austria odzyskałaby wolność, a Niemcy zostałyby podzielone wzdłuż Dunaju i Wezery na południowe - katolickie i północne - protestanckie. Za niedopuszczalne uznała powstanie jednolitych ideowo Stanów Zjednoczonych Europy. Ich luźna struktura nie powstrzymałaby Niemiec przed gospodarczą i wojskową hegemonią. Państwa Europy Środkowej utworzyłyby ścisły blok państw narodowych, aby uniknąć przymusowej integracji przez Niemcy (Mitteleuropa) i ZSRR (radzieckie republiki). Doświadczenia wojenne uświadomiły im wyższość interesu wspólnotowego nad egoizmem narodowym. Konfederacja polsko-czechosłowacka jednoczyłaby część północną obszaru ABC. Opierałaby się na wspólnym kierownictwie politycznym i gospodarczym. Blok środkowoeuropejski Polska budowałaby z czeskimi narodowcami i agrariuszami, a nie E. Benešem. Po wojnie Czesi i Słowacy zdecydowaliby o swoim związku politycznym. Następie zostałby rozszerzony o Rumunię i Węgry. Litwa byłaby polskim protektoratem ze swobodnym rozwojem narodowym za uległość wobec Niemiec i ZSRR. Za „trianońską krzywdę” (I920) Węgry zatrzymałyby Ruś Podkarpacką

50 „Prus” (Tadeusz Maciński), U podstaw zagadnienia granicy zachodniej, „Głos”, 11 VI 1942, s. 3; AAN, DIP, sygn. 202/III-91, De Gaulle, „Państwo Narodowe”, 10 II 1944, nr 1, s. 17.

51 „Prus”, U podstaw zagadnienia granicy zachodniej, „Głos”, 11 VI 1942, s. 1-2; „Lar” (Z. Domański), Problem granicy wschodniej, „Głos”, 9 VII 1942, s. 1-3; „1723”, O stara granicę Piastów. Przed doniosła decyzja, „,Głos”, 21 VIII 1943, s. 2-5; „Prus”, Nasze stanowisko w sprawie wschodniej granicy Polski, „Głos”, 29 I 1944, s. 1-2; zob. P. Eberhardt, op. cit., s. 174.

52 BN, mf. 54706, J. Kaliski, Państwo Zachodniostowiańskie, s. 9-27; zob. S. Fertacz, Polska myśl stowiańska w okresie drugiej wojny światowej, Katowice 2000, 62-65.

53 „Prus”, Łużyce organizuja się, „Głos”, 28 XI 1942, s. 1; „Prus”, Jeszcze o Łużycach, „Głos”, 6 II 1943, s. 1; „4044”, Łużyce i ich realna podstawa wyjściowa, „Głos”, 1 I 1944, s. 1-4.

54 „Cz.”, O idei jagiellońskiej i co z niej wynikło, „Głos”, 18 XII 1943, s. 1-6.

55 AAN, DR, DSZ, sygn. 202/XIV-16, „Lar”, Problem granicy wschodniej, „Głos”, 9 VII 1942, s. 1-3; idem, Pótnocno-wschodnia ściana, „Głos”, 6 II 1943, s. 2-3; idem, Białoruś - zapomniana i zaniedbana córa Polski, „Głos”, 29 V 1943, s. 1-3; idem, Granica pótnocno-wschodnia Polski, „Głos”, 12 VI 1943, s. 2-4.

56 AAN, DR, DSW, sygn. 202/II-22, Deklaracja ideowa grupy „Ojczyzna”, 14 XII 1942, s. 118-129; DIP, sygn. 202/III-61, Jan Moszyński, Zygmunt Wojciechowski, Stosunki polsko-niemieckie i problem Europy Środkowej, wyd. Biblioteka Wielkopolska, D.I. Druk, Warszawa 24 V 1941, s. 26, Sprawozdanie z wydawnictw propagandowych, nr 160/43, 18 XI 1943, s. 25-26; , Ojczyzna” 1939-1945, dokumenty, wspomnienia, publicystyka, red. Z. Mazur, A. Pietrowicz, Poznań 2004, s. 359-370; Federacja polsko-czeska podstawa ładu środkowoeuropejskiego, „Kraj”, 27 VII 1943, nr 2, s. 1-2. 
i ziemie z mniejszością węgierską na Słowacji i Rumunii. Oddaliby obszary zajęte w I94I r. Jugosławii za jej walkę zbrojną. Związek środkowoeuropejski zrealizowałby hasło Polski od morza do morza. Była to geopolityczna konieczność, aby wypchnąć z międzymorza bałtycko-czarnomorskiego wpływy ZSRR do granic cywilizacji polskiej - Dźwiny, Bramy Smoleńskiej i Dniepru. Z pomocą Grecji Bałkany integrowałaby federalna Jugosławia, tworząc z Bułgarią Wielką Jugosławię. Jeśliby nie powstałby blok bałkański, to Jugosławia byłaby częścią środkowoeuropejskiego. Blok skandynawski wyeliminowałby razem ze środkowoeuropejskim Niemców z Bałtyku.

Polska odzyskałaby linię Odry i Nysy Łużyckiej57. Zaolzie pozostałoby w jej granicach. Posiadałaby wybrzeże bałtyckie od Rugii, Uznamu, Wolina, Zalewu Szczecińskiego do Litwy. Obszar między Odrą i Nysą Łużycką a granicą ryską był niepodzielny na żadne inne państwa (Wielka Polska) ${ }^{5}$. Przewodziłaby w Europie Środkowej jako państwo narodowe, unitarne, katolickie i autorytarne z racji największego potencjału terytorialnego, demograficznego, gospodarczego i wojskowego ${ }^{59}$. Niemcy i Żydzi opuściliby Polskę. Obywatelstwo z urodzenia otrzymywaliby Polacy, a mniejszości za zasługi dla Polski. Europa opierałaby się na regionalnych związkach państw równoprawnych z mocarstwami. W stosunkach międzynarodowych obowiązywałyby moralność chrześcijańska, prawo międzynarodowe i zakaz wojen. Agresor zostałby wykluczony ze społeczności międzynarodowej. Obszar ABC Polska jednoczyłaby w sojuszu z zachodnimi mocarstwami i Turcją, z którymi gwarantowałaby pokój w Europie. Mogły rządzić tylko historyczne narody. Trudno było równać z Polską Litwę czy inne mniejsze narody wykształcone w XIX w., które powinny podporządkować się większym $^{60}$. Litwini, Białorusini i Ukraińcy za współpracę z Niemcami i ZSRR nie otrzymaliby niezależnych państw. Z powodu niskiej świadomości narodowej Białorusini weszliby w skład Polski. Ukraińcy stworzyliby z czasem państwo za ryską granicą w sojuszu z Polską.

Secesja SN propagowała powstanie Wielkiej Polski z granicą na lewym brzegu Odry i Nysy Łużyckiej oraz wybrzeżem od Rugii po ujście Dźwiny ${ }^{61}$. Na zachodzie sąsiadowałyby z nią Łużyce. Rozszerzenie polskich wpływów za granicą ryską na narody wschodnie secesja SN odkładała do czasu zrealizowania programu zachodniego. Z ziem polskich zostaliby usunięci Niemcy i Żydzi. Na obszarze ABC główną siłę polityczną stanowiliby Słowianie Zachodni w ,polskim systemie politycznym” państw narodowych. Narody słowiańskie posiadałyby równe prawa i obowiązki. Narodowa i katolicka Polska musiała podjąć solidarny wysiłek przemysłowy, zbrojeniowy i kulturowy całego narodu, aby stworzyć ,wielką zachodniosłowiańską cywilizację". Uwolniłaby Europę Środkową od wpływów europejskich

\footnotetext{
57 Pomorze, Wielkopolska, Śląsk, „Biuletyn Zachodni”, sierpień 1943, nr 3, s. 10; Główny cel wojny, „Kraj”, 3 V 1944, nr 15, s. 4-6.

58 K. Szajnocha (Z. Wojciechowski), Szkice historyczne, (t. 1, Warszawa 1938, 1943), w: „, Ojczyzna” 1943-1945, s. 411-415.

59 Warunek sity przyszłej Polski, „Kraj”, 15 VII 1943, nr 1, s. 2-4.

${ }^{60}$ Problem tzw. mniejszych państw, „Kraj”, 21 XII 1943, nr 17, s. 3-6; Tajemnica Europy, „Kraj”, 21 XII 1943 , nr 17, s. 1-3, (przedruk art. Jana Remblińskiego z londyńskiej „Sprawy”, mówiący o specyfice i odrębności twórczej, ideowej, politycznej, gospodarczej Europy od pozostałych kontynentów i ZSRR).

${ }^{61}$ AAN, DR, BP, sygn. 202/I-54, Uchwała o granicach, Ogólnopolski Zjazd Delegatów SN, Warszawa styczeń 1943, s. 313a, Uchwała o Wielkiej Polsce, s. 313a; Uchwała o Państwie Narodowym, s. 313a; Uchwała Polska w Europie, s. 314; DIP, sygn. 202/III-83, Zjazd działaczy SN Q.V., „Polski Informator Narodowy”, 3 II 1943, nr 3, s. 10; sygn. 202/III-86, Na drodze do Wielkiej Polski, „Wielka Polska”, 13 IV 1944, nr 3, s. 77; NSZ, sygn. 207/39, TNRP, O co walczy Ruch Narodowy, 1943, s. 4-4a.
} 
mocarstw i gwarantowała trwały pokój na kontynencie. Związek w postaci unii celnej i walutowej oraz obronnej na czele z Polską przyniósłby narodom środkowoeuropejskim siłę i potęgę na arenie międzynarodowej. W czasie wojny za antypolską działalność mniejszości narodowych odpowiadali piłsudczycy, którzy wysuwali plany federacyjne i prometejskie wobec narodów wschodnich, zamiast je asymilować. Prawa obywatelskie byłyby im przyznawane indywidualnie za walkę o niepodległość Polski. Za zbrodnie na Polakach Ukraińcy zostaliby wysiedleni z Ziem Południowo-Wschodnich. Pokój z ZSRR wymagał rezygnacji z granicy z I772 r., ale ryska byłaby poprawiona na bardziej strategiczną w kierunku wschodnim $^{62}$. Secesja SN nie popierała samostanowienia Białorusinów i Ukraińców. Litwa zostałaby wcielona do Polski. Węgry zatrzymałyby Ruś Podkarpacką i Bukowinę, aby nie dopuścić do granicy czechosłowacko-radzieckiej. Idea federacyjna była propagowana przez wrogów idei narodowej (socjaliści, demokraci, liberałowie, masoni i komuniści), którzy w federacji zniszczyliby państwo narodowe i wspólnotę narodową ${ }^{6}$. Koncepcja federacyjna rządu realizowałaby brytyjskie interesy. Dzieliła obszar ABC na mniejsze jednostki geopolityczne wokół Polski i Jugosławii. Europę Środkową pozbawiało to równoważącej siły wobec niemieckiej i radzieckiej potęgi, utrzymując jej zależność od zachodnich mocarstw. Secesja SN sprzeciwiała się każdemu wariantowi federacji w skali Europy, środkowoeuropejskiej i z narodami wschodnimi. Odrzucała współpracę z proradzieckim i masońskim E. Benešem, który układem z ZSRR z I943 r. oddał narody Europy Środkowej w jego niewolę, niszcząc dla niej jedyną wolnościową polską alternatywę. Idea federacyjna rządu i ugrupowań w kraju była ideowo obca narodowi polskiemu i degradowała jego znaczenie wobec pozostałych narodów środkowoeuropejskich. Groziła rozbiorem historycznych ziem polskich przez sąsiednie narody, które były jego wrogami (Litwini, Białorusini, Ukraińcy). Zbudowana na polskim obszarze historycznym zgodnie z ideą narodową Wielka Polska strzegłaby wolności narodów Europy Środkowej przed Niemcami i ZSRR.

Organizacja Polska (Grupa „Szańca”) uważała ideę federacyjną za wrogą idei narodowej64. Wysuwali ją socjaliści (federacja socjalistyczna, autonomia dla mniejszości narodowych), syndykaliści (syndykalistyczny związek narodów Europy), komuniści (radzieckie republiki), demokraci (federacje regionalne), liberałowie (liberalizm gospodarczy, demokracja parlamentarna), piłsudczycy (federacja z narodami wschodnimi), ludowcy (konfederacja chłopska). Żydowską mrzonką było jedno państwo komunistyczne w Europie, a masońską Paneuropa, niszczące państwa narodowe i historyczne narody. OP odrzucała ,absurdalne” pomysły z antykwariatu Ligi Narodów - unia demokratycznych państw Europy (Stany Zjednoczone Europy), armia europejska czy światowa, strzegąca pokoju i bezpieczeństwa (Rada Europy Churchilla, ONZ Roosevelta), bazy alianckie wokół Niemiec i gwarancje pokoju w Europie

${ }^{62}$ AAN, DR, DIP, sygn. 202/III-80/t.2, Niebezpieczeństwo granicy czesko-sowieckiej, „Wielka Polska”, 19 VI 1943, s. 429; sygn. 202/III-81, Czy możemy dopuścić do powtórzenia się 1939 roku, „Narodowa Agencja Prasowa", 28 VI 1944, nr 6, s. 160.

${ }_{63}$ AAN, DR, DIP, sygn. 202/III-86, Głos angielski za państwem zachodniostowiańskim, „Wielka Polska”, 20 IV 1944, nr 4, s. 76; sygn. 202/III-39, Negatywny stosunek wobec koncepcji federacyjnej, „Narodowa Agencja Prasowa”, 13 VI 1944, nr 5, s. 36; sygn. 202/III-88, Polityka Benesza, „Narodowa Agencja Prasowa”, 13 VI 1944, nr 5, s. 16.

${ }^{64}$ AAN, DR, DIP, sygn. 202/III-82, Jaka chcemy mieć Polskę, broszura „Szańca” i „Pobudki”, Sprawozdanie prasowe nr 5a, 27 X 1941, s. 26-27; Polska ideologia wojskowa, „Naród i Wojsko”, listopad 1941, nr 1, s. 2; Polska trzech W, „Szaniec”, 1942, nr 20, w: „Myśl”, styczeń 1942, nr 2, s. 16, (Po Polsce A, B i C, a przed Polską Trzech Mórz, musi być Polska trzech W: Wodzów, Wojska i Walki). 
w oparciu o sojusz polsko-brytyjski (plany rządu W. Sikorskiego). Umowy polsko-czechosłowacka i jugosłowiańsko-grecka z I942 r. były pomysłem zachodnich demokracji65. Między Niemcami i ZSRR zamierzały stworzyć z małych państw zależne od nich słabe regionalne federacje. Z racji tradycji unijnych Polska nie potrzebowała antynarodowej idei federacyjnej. O związkach państwowych decydowałyby zainteresowane narody, a nie emigracyjne rządy. W unii z narodowymi Czechami, a nie masońską Czechosłowacją E. Beneša, dominowałaby Polska. Materialistyczny i proradziecki naród czeski nie posiadał uniwersalistycznych idei, ducha walki i interesów w skali Europy. OP nie wykluczała w dłuższej perspektywie fuzji obu państw, ale bez ustroju demokratycznego. To liberalna demokracja, prawo międzynarodowe w zakresie wojny i pokoju oraz prawa człowieka, za którymi stał Zachód i E. Beneš, doprowadziły do upadku Czechosłowacji. OP przyznawała prawo katolickiej Słowacji do niepodległości lub autonomii w Polsce.

Polska nie mogła jednocześnie prowadzić polityki zachodniej i wschodniej. Po wojnie realizowałaby koncepcję geopolityczną zgodną z ideą narodową ${ }^{66}$, aby ponownie nie uległa rozbiciu na dwie orientacje, jak po I wojnie światowej. Rozszerzanie granicy ryskiej na wschód osłabiłoby naród polski wobec mniejszości narodowych. Wschodni federalizm lewicy i piłsudczyków groził wojną z ZSRR i tworzeniem obcych państw na polskim obszarze historycznym. Ważniejsze od przesuwania granicy ryskiej na wschód (do I943 r. OP planowała poprawki strategiczne na Mińszczyźnie i Żytomierszczyźnie) było osiągnięcie granicy na Odrze i Nysie Łużyckiej, wybrzeża od Rugii po ujście Niemna, powstanie Łużyc, wcielenie Litwy do Polski. Na południu graniczyłaby z Węgrami, a Zaolzie zostałoby w jej granicach. Federacja z Białorusią i Ukrainą groziła niemiecką i radziecką infiltracją ${ }^{67}$. Niezdolni do powołania własnych państw Litwini, Białorusini i Ukraińcy dojrzewaliby w ramach Polski. Za powrót do granicy ryskiej i nieingerencję w sprawy wewnętrzne Polski OP deklarowała ZSRR wspólne zwalczanie ich dążeń niepodległościowych. Gdyby chciał zniewolić lub okroić Polskę, to z Japonią dążyłaby do jego rozbicia. W ramach federacji Polska nie obroniłaby Estonii, Łotwy, Białorusi i Ukrainy przed ZSRR. Narody wschodnie chciały polskich ziem, a nie federacji. Po ekspansji na zachód następne pokolenie rozszerzałoby polskie wpływy na wschód.

Dla Polski lepszym kierunkiem do tworzenia związków państw był obszar naddunajski ${ }^{68}$, ponieważ dawał bardziej realne korzyści polityczne, gospodarcze i militarne niż wschodni. Nie prowadził do sporów z ZSRR, a wypychał niemieckie wpływy z Europy Środkowej. Niemcy zostałyby okrojone przez Polskę, Francję, Danię i Czechy. Austria, Bawaria, Badenia i Wirtembergia opuściłyby Rzeszę Niemiecką. Zagłębia Sary i Ruhry byłyby przez dłuższy czas okupowane. Polska organizowałaby Europę Środkową jako najsilniejsze państwo zachodniej Słowiańszczyzny, tworząc narodową wspólnotę obronną i gospodarczą. OP nie

\footnotetext{
65 Polacy na wszystkich frontach, „Naród i Wojsko”, styczeń 1942, nr 1, s. 1-2; Kierunek ekspansji, „Naród i Wojsko”, kwiecień 1942, nr 4, s. 1-3; AAN, KG AK, BIP, sygn. 203/VII-48, Układ polsko-czeski, „Szaniec”, 31 I 1942 , nr 77, s. 114; Układ polsko-czeski, „Szaniec”, 15 II 1942, nr 78, s. 114; DR, DIP, sygn. 202/III-83, Akt konfederacji polsko-czeskiej, „Szaniec”, 1 I 1943, nr 1, s. 1.

${ }^{66}$ AAN, DR, DIP, sygn. 202/III-80/t.2, Na rozstajnych drogach, „Szaniec”, 22 IX 1943, nr 12, s. 512-513.

67 AAN, DR, DSW, sygn. 202/II-11, Wobec zagadnienia ukraińskiego, „Placówka”, 1 I 1943, nr 1, s. 268; DIP, sygn. 202/III-81, Ogniem i mieczem, „Praca i Walka”, 15 I 1944, nr 2, s. 9.

${ }^{6}$ Nic bez nas w Europie, „Naród i Wojsko”, styczeń 1943, nr 1, s. 4; AAN, KG AK, BIP, sygn. 203/VII-50, Węry, „Placówka”, 28 II 1942, nr 5, s. 46; DR, DIP, sygn. 202/III-80/t.1, Uchwała Rady Narodowej w sprawie granic, „Szaniec”, 1 I 1943, nr 1, s. 16; Nad Odrę, „Placówka”, 1 I 1943, nr 1, s. 16.
} 
wykluczała jej budowy przy pomocy polskiej armii. Wspólnota gospodarcza uwolniłaby państwa środkowoeuropejskie od zależności finansowej i gospodarczej mocarstw. Polska byłaby arbitrem w granicznych sporach między nimi. Węgry zatrzymałyby ziemie Czechosłowacji i Rumunii z mniejszością węgierską. Bułgaria zajęłaby rumuńską Dobrudżę. Polska ekspansja kierowałaby się na Skandynawię i Bałkany, aby uniknąć niemieckiej i radzieckiej blokady. Polską strefą bezpieczeństwa była Europa Środkowa i Południowa oraz państwa bałtyckie, a naturalnymi sojusznikami Szwecja, Włochy i Turcja. Związek środkowoeuropejski powstałby na zasadzie ścisłego sojuszu w zakresie polityki zagranicznej, gospodarczej i wojskowej, a w pozostałych obszarach współpraca byłaby konsultatywna. Stanowiłby on podstawę mocarstwowości Polski w Europie. Uczestnictwo w bloku wynikałoby z interesu narodowego państw, a nie z przymusu i podboju. Bezpieczeństwo w Europie opierałoby się na umowach dwu i wielostronnych państw, a nie federacjach. Idea federacyjna prowadziła do wojny z ZSRR, narzucenia Polsce demokracji parlamentarnej i liberalnego kapitalizmu, równouprawnienia z mniejszościami narodowymi, utraty polskich Ziem Wschodnich na rzecz sfederowanych narodów ${ }^{69}$.

Narodowe Siły Zbrojne walczyły o Odrę i Nysę Łużycką, Śląsk, Ziemię Lubuską, Rugię, Uznam, Wolin, Prusy Wschodnie oraz wcielenie Litwy do Polski, a na wschodzie o granicę ryską. Na obszarze ABC miał powstać Związek Zachodniosłowiański pod kierownictwem Polski ${ }^{70}$. Wielka Polska byłaby narodowa, a przeznaczeniem mniejszości narodowych była asymilacja z narodem polskim. NSZ opierały powojenny system bezpieczeństwa Polski na organizacji Europy Środkowej ${ }^{71}$, a nie na nowej Lidze Narodów czy wielostronnym systemie bezpieczeństwa międzynarodowego. Słabością II Rzeczypospolitej były walki klasowe lewicy i awantury federacyjne i narodowościowe piłsudczyków. Wielka Polska oznaczała marsz na zachód po granice piastowskie, a dopiero potem po jagiellońskie, $\mathrm{z}$ wykluczeniem federacji. Stworzyłaby łacińskie imperium na obszarze ABC chroniące małe narody przed Niemcami i ZSRR. Paneuropa, Stany Zjednoczone Europy, Związek Europejskich Republik Radzieckich zagrażały niepodległości Polski. Federacja środkowoeuropejska stanowiła słabą strukturę geopolityczną, aby budować na niej trwały pokój i bezpieczeństwo. $Z$ zasady zakłada brak dominacji jakiegoś państwa. W strukturach wielostronnych musiał być podmiot dominujący nad pozostałymi uczestnikami, co wynikało z różnicy potencjałów państw. Federacja była formą bezideową, mało spójną, łatwą do ingerencji z zewnątrz. Wszystkie współczesne projekty federacyjne były wrogie wielkiej, katolickiej i narodowej Polsce, i jej koncepcji imperium. Idea federacyjna osłabiała znaczenie Polski w Europie i nie dałaby jej bezpieczeństwa. W ramach federacji europejskiej znaczyłaby tyle co Szwajcaria. Jej realizacja pod zwierzchnictwem Wielkiej Brytanii jako Stany Zjednoczone Europy (Rada Europy) była nie do zrealizowania ze względu na zróżnicowanie polityczne, gospodarcze i kulturowe europejskich państw. Idea ta w skali europejskiej i regionalnej niosła groźbę okrojenia terytorialnego historycznej Polski na rzecz niepodległych narodów wschodnich. Oznaczało to kolejny rozbiór ziem polskiej cywilizacji. Od upadku I Rzeczypospolitej te narody zawsze szkodziły polskim interesom narodowym. Odmawiały związków z Polską, wybierając raz Niemcy,

\footnotetext{
69 AAN, DR, DIP, sygn. 202/III-80/t.1, Jak w madrym Rzymie, „Szaniec”, 29 I 1943, nr 3, s. 79.

70 AAN, DR, DIP, sygn. 202/III-86, A. Rawicz (Jan Lilpop), O co walcza Narodowe Sity Zbrojne, 1943, s. 40-41.

71 AAN, NSZ, Oddział III, sygn. 207/23, Służba Wychowawczo-Oświatowa NSZ, Na drodze do Wielkiej Polski, 1943, s. 1-3; Propaganda idei uderzenia na zachód, 1943, s. 9; Misja dziejowa Polski, 1943, s. 50-55; Prawdy historyczne, s. 56-60; Rachunek, „Chrobry Szlak”, 24 VI 1943, nr 7, s. 1-3.
} 
raz Rosję. NSZ akceptowały unię tylko z narodowymi Czechami ${ }^{72}$. Polityczne i wojskowe sprawy prowadziłaby Polska, a Czechy gospodarcze. Oba państwa zbudowałyby Związek Środkowoeuropejski. Za jego pośrednictwem propagowałaby ideę narodową i katolicyzm. Umowy polsko-czechosłowacka i jugosłowiańsko-grecka z I942 r. były w interesie zachodnich mocarstw oraz różnego rodzaju antynarodowych międzynarodówek. Struktura federacyjna niszczyła atrybuty państwa narodowego w stosunkach międzynarodowych ${ }^{73}$. Litwa stałaby się częścią Polski, a Łotwa i Estonia weszłyby z nią w ścisły związek. Polska wzięłaby pod swój protektorat Rumunię, która była niezdolna do obrony swojej niezależności i terytorium. Ruś Podkarpacka pozostałaby w ramach Węgier dla wspólnej granicy z Polską. Na swoim historycznym obszarze Polska nie była imperialistyczna. Narody wschodnie za sojusz z jej okupantami nie mogły być niezależne nawet w unii z nią74.

Konfederacja Narodu („Falanga”, Ruch Narodowo-Radykalny) dążyła do rozbicia ZSRR i okrojenia Niemiec, aby między nimi zbudować Imperium Słowiańskie ${ }^{75}$. Tylko tak zorganizowana przez Polskę Europa Środkowa obroniłaby się przed ich imperializmem, ustanowiła równowagę w Europie i zaprowadziła trwały pokój. Wojna niemiecko-radziecka miała doprowadzić do rozpadu ZSRR i okrojenia Niemiec przez ich sąsiadów. Żadna międzynarodowa organizacja, typu Liga Narodów, z prawem zakazu wojen nie zabezpieczyłaby Polski przed ich jednoczesną agresją. Na zachodzie granica imperium z Niemcami biegłaby od Rugii, Odrą, zachodnią granicą państwa łużyckiego i Nysą Łużycką, na północy Prusy Wschodnie i Gdańsk. Litwa i Białoruś (odnowiona unia lubelska) weszłyby w skład Polski, a Łotwa, Estonia i Ukraina w unię z nią. Na wschodzie granica szłaby wzdłuż linii z I772 r. Polska strefa wpływów w Europie Środkowej biegła od Bałtyku przez Szczecin do Triestu (granica Europy Zachodniej i Środkowej Łaba - górny Dunaj), Morze Adriatyckie, Egejskie, Czarne, na wschodzie linia Leningrad - Rostów (granica Europy Wschodniej i Środkowej Don). Niemcy straciłyby wszystkie ziemie należące do Słowian. Obszar między Odrą i Dnieprem, Bałtykiem a Dunajem i Morzem Czarnym był naturalnym miejscem osiedlenia dla Polaków ${ }^{76}$. Niemcy zostaliby usunięci z Imperium Słowiańskiego, które po objęciu międzymorza bałtycko-czarnomorskiego odcięłoby ZSRR od Bałkanów. Jego potencjał gospodarczy i militarny równoważyłby niemiecki i rosyjski. Uodporniłby się od zmiennych interesów zachodnich sojuszników. Dążenie do państw narodowych na historycznych ziemiach polskich Litwinów, Białorusinów i Ukraińców wynikał z błędnej polityki wschodniej i narodowościowej piłsudczyków. Budowane na zasadach narodowych i katolickich Imperium

\footnotetext{
72 AAN, NSZ, sygn. 207/6, Blok Środkowoeuropejski, Raport 7/73/43, 1943, s. 40; Polityka polska a rzeczywistość, „Chrobry Szlak”, 15 IX 1943, nr 10, s. 2.

73 AAN, NSZ, Oddział III, sygn. 207/23, SW-O NSZ, Program Wielkiej Polski, 1943, s. 11-12; Polityka polska a rzeczywistość, „Chrobry Szlak”, 15 IX 1943, nr 10, s. 1.

74 Nie damy wschodu Polski, „Narodowe Siły Zbrojne”, 30 VI 1944, nr 8, s. 2.

75 Pokolenie Polski Wielkiej, „Nowa Polska”, 25 IV 1941, nr 1, w: Program „,Nowej Polski, „Myśl”, wrzesień 1941, nr 2, s. 4-7; AAN, DR, DIP, sygn. 202/III-82, Czy Polska może być niepodległa, „Nowa Polska”, 22 XII 1941, nr 15, s. 72; Granice Europy Środkowej, „Biuletyn Słowiański” (BS), 8 XI 1943, nr 6, s. 3-8; zob. A. Dudek, G. Pytel, Bolesław Piasecki. Próba biografii politycznej, Londyn 1990, s. 127; E. Ponczek, Dyskurs o kulturze ..., s. 26-27.

76 AAN, DR, DIP, sygn. 202/III-82, Imperium Stowiańskie „,Nowej Polski”, Sprawozdanie tygodniowe nr 7/42, 28 I 1942, s. 51; Biuro Prezydialne (BP), sygn. 202/I-35, Wschód Polski, „Nowa Polska”, 12 X 1943, nr 60, s. 149; Przez Polskę narodową do Polski katolickiej, nie na odwrót, „Fakty na Tle Idei”, 4 IX 1941, nr 3, s. 1-3; Idea wielkiego pokolenia, „Do Broni”, 20 V 1942, nr 8, s. 1; Międzymorze baltycko-czarnomorskie, „Do Broni”, 29 VI 1942, nr 11, s. 5; Imperializm i czyn, „Do Broni”, 31 III 1943, nr 4, s. 1-3; zob. S. Fertacz, Polska myśl słowiańska..., s. 40.
} 
Słowiańskie zjednoczyłoby ziemie polskie należące do Piastów i Jagiellonów. W jego ramach każdy naród mógłby się swobodnie rozwijać, ale kierownictwo należałoby do Polaków. Bez Białorusi i Ukrainy Imperium Słowiańskie nie miałoby racji bytu77. Unia Polski z Ukrainą była ważniejsza od związku z Czechami. KN zakładała wojnę z ZSRR o granicę ryską i niezależność narodów wschodnich.

KN odrzucało budowanie federacji w Europie Środkowej na ideach socjalistycznych, agrarnych, liberalno-demokratycznych i piłsudczykowskich, które rozbijały polskie ziemie historyczne ${ }^{78}$. Układy polsko-czechosłowacki i jugosłowiańsko-grecki z 1942 r. ułatwiały budowę Imperium Słowiańskiego ${ }^{79}$. Jako związki regionalne nie zrównoważyłyby siły i potęgi Niemiec i ZSRR. KN popierała koncepcję federacyjną W. Sikorskiego, bo inicjowała jedność narodów między Niemcami i ZSRR. Podstawą Imperium Słowiańskiego byłaby unia polsko-czesko-słowacko-serbołużycka, a nie Czechosłowacja E. Beneša, która ze wspólnymi instytucjami stanowiłaby model integracji. Związek zachodniosłowiański połączyłby się przez Rumunię i Węgry z Wielką Jugosławią (z Bułgarią i Albanią), będącą w unii z Grecją. W imperium Węgry hamowałyby wpływy ZSRR na Czechów, Słowaków i Serbów. Eliminacja wpływów Niemiec z obszaru naddunajskiego wymagała jego przebudowy etniczno-terytorialnej. Skorzystałyby na tym Węgry kosztem Czechosłowacji (południowa Słowacja, Ruś Podkarpacka), Rumunii (Siedmiogród) i Jugosławii. W zamian Słowacja dostałaby północny Burgenland, a południowy Jugosławia, która przejęłaby od Austrii i Włoch obszary z ludnością słowiańską. Bułgaria odebrałaby Rumunii Dobrudżę. KN nie przeszkadzało, że obszar ABC byłby integrowany na północny przez Polskę, a na południu przez Jugosławię $e^{80}$. Od intryg brytyjskich większe zagrożenie dostrzegała w proradzieckiej polityce E. Beneša, utrudniającej budowę Imperium Słowiańskiego. Z jego powodu KN była za federalizacją Czechosłowacji lub jej podziałem na Czechy i Słowację. W przypadku wielonarodowej Jugosławii była za jej centralizacją, ale z równymi prawami dla Serbów i Chorwatów. Po zerwaniu stosunków z Polską przez ZSRR KN wzywała do przyspieszenia procesu łączenia się narodów środkowoeuropejskich w ramach Imperium Słowiańskiego. Po śmierci W. Sikorskiego żądała kontynuowania jego planu federacji regionalnych ${ }^{81}$. Były niezbędne w pierwszym etapie budowy państwa związkowego. Z rozczarowaniem KN odbierała brytyjską i amerykańską politykę, które w I943 r. zaprzestały popierania federacji w Europie. Za zdradę państw i narodów Europy Środkowej KN uznało grudniowy układ E. Beneša ze Stalinem w I943 r., który przekreślił powstanie Imperium Słowiańskiego.

\footnotetext{
77 Skromne postulaty PRN, „Do Broni”, 16 XII 1942, nr 21, s. 8; Humań czy Hadziacz?, BS, 30 VI 1943, nr 5, s. 2; Granice Ukrainy, BS, 6 XII 1943, nr 7, s. 2-4.

78 Do firmowych działaczy katolickich, „Fakty na Tle Idei”, 1 XI 1941, nr 7, s. 4; Przekleństwo mówienia, „Do Broni”, 5 V 1942, nr 7, s. 1; Międzynarodowa i narodowa solidarność, „Do Broni”, 12 VII 1942, nr 12, s. 5-6.

79 Ku imperium, „Do Broni”, 25 VIII 1942, nr 15, s. 1-2; Sojusz Grecji z Jugosławia i konfederacja polsko-czechosłowacka, „Do Broni”, 4 II 1942, nr 4, s. 5; Z emigracji i z ziem słowiańskich na emigracji, BS, październik 1942, nr 8, s. 16-17; Konfederacja polsko-czeska, BS, listopad 1942, nr 9, s. 9; Sprawa Węgier na tle zagadnień słowiańskich, BS, 31 I 1943, nr 1, s. 2-4.

80 Imperium to jedność Stowian - w jedności sita, „Do Broni”, 8 XII 1943, nr 12, s. 1.

81 Testament Sikorskiego, BS, 8 XI 1943, nr 6, s. 1-3; AAN, DR, DIP, sygn. 202/III-86, Prasa aliancka o problemie federacji, „Nowa Polska. Wiadomości Codzienne”, 23 XI 1943, nr 248, s. 6; Problem federacji wśród aliantów, „Nowa Polska”, 8 XII 1943, nr 63, s. 6.
} 
„Pobudka” zakładała polityczny, gospodarczy i wojskowy związek państw Europy Środkowej, który rozwiązywałby też spory między nimi ${ }^{82}$. Popierała związki regionalne w Europie propagowane przez W. Sikorskiego w sojuszu z zachodnimi mocarstwami, w szczególności współpracę polsko-czeską (na wzór unii polsko-litewskiej). Rolę organizacyjną przyznawała Polsce jako największemu państwu w Europie Środkowej i za jej wkład w wojnę. Postulowała jak najszybsze powołanie unii celnej i walutowej polsko-czesko-słowackiej j3. Za dostęp do polskiego rynku Czesi mieliby obowiązek lokowania inwestycji i środków finansowych w Polsce, rozbudowując jej potencjał gospodarczy. W sferze polityki zagranicznej i wojskowej dominowałaby Polska. Ścisła unia polsko-czesko-słowacka musiała stać się środkowoeuropejskim mocarstwem, a nie kopią Małej Ententy (międzyrządowa współpraca Czechosłowacji, Rumunii i Jugosławii). Szybka integracja gospodarcza i wojskowa poprawiłaby poziom życia i bezpieczeństwa narodów, co dałoby ich zgodę na integrację polityczną i na akcesję do unii kolejnych państw obszaru ABC. Do związku z Polską musiała należeć Litwa, aby weszły do niego Estonia i Łotwa. Inaczej czekała je radziecka okupacja. Głównym zadaniem związku środkowoeuropejskiego była kontrola Niemiec. Zostałyby rozbite na protestanckie i katolickie. Austria, Badenia, Wirtembergia i Bawaria wchodziłyby do związku środkowoeuropejskiego, aby uniemożliwić odtworzenie kolejnej Rzeszy. Ich politykę zagraniczną i wewnętrzną kontrolowałyby organy związku, które nadałyby im konstytucje z podziałem na kompetencje narodowe i związkowe. Do Łaby Niemcy byłyby okupowane przez polskie wojska. Unia Jugosławii, Grecji i Bułgarii przyjaźnie współpracowałaby z Włochami. Te utworzyłyby z Hiszpanią i Francją unię łacińską. „Pobudka” sprzeciwiała się radzieckiej idei słowiańskiej, federacji komunistycznych republik Europy i niemieckiej Paneuropie, prowadzących do ich hegemonii ${ }^{84}$. Koncepcja państwa światowego i federacji europejskiej były nie do zrealizowania z powodu różnic narodowych i kulturowych oraz potencjałów państw. Nie dopuszczała myśli o utworzeniu federacji regionalnych i Europy na bazie ideologii liberalno-demokratycznej, chłopskiej, socjalistycznej i komunistycznej. Postulowała spisanie zasad europejskiej współpracy w Karcie Europy, gwarantującej poszanowanie praw małych i dużych państw ${ }^{85}$. System pokojowy opierałby się na Karcie Atlantyckiej i równoważących siłę mocarstw federacjach regionalnych w Europie oraz światowym systemie gospodarczym, znoszącym bariery surowcowe, handlowe i migracyjne za pracą ${ }^{86}$.

Zachodnia doktryna samostanowienia po I9I8 r. nie przystawała do Europy Środkowej i Wschodniej, gdzie terytoria historycznych państw i narodów zostały rozbite przez Austrię, Prusy, Rosję i Turcję. Rozbudziło to nadmierne nadzieje młodych narodów wschodnich do posiadania niezależnych państw, które przeciwko narodowi polskiemu wspierały od XIX w. Niemcy, Austria i Rosja. Te nie zamierzały tworzyć ich państw, tylko je okupować. „Pobudka" nie odmawiała im niepodległości ${ }^{87}$, ale na terytorium ZSRR. Polska związałaby ścisłą

\footnotetext{
82 Polska a pokój, „Pobudka”, luty 1942, nr 2, s. 4-11; Polska a małe narody, „Pobudka”, luty 1942, nr 2, s. 11-16.

83 Unia gospodarcza, „Pobudka”, lipiec 1942, nr 6, s. 15-21.

84 Istota przemian społecznych w Polsce, „Pobudka”, wrzesień 1941, nr 5, s. 20-21; AAN, DR, DSW, sygn. 202/ II-22, „Pobudka”, luty 1943, s. 154-155.

85 Rola Polski wśród zwycięzców, „Pobudka”, luty 1942, nr 2, s. 1-4.

${ }^{86}$ Imperializm czy pacyfizm, „Pobudka”, styczeń 1942, nr 1, s. 29-32; Europa w dniu zwycięstwa, „Pobudka”, czerwiec 1942, nr 5, s. 7-9, 11.

87 Namiętności ukraińskie i białoruskie, „Pobudka”, sierpień 1942, nr 7, s. 19-22; Drogi do jedności, „Pobudka”, maj 1944, nr 1, s. 14.
} 
unią Litwę (autonomia), a na arenie międzynarodowej zabiegałaby o wolność dla Białorusi i Ukrainy, ale nie toczyłaby o to wojny z ZSRR. Granica na zachodzie biegłaby Odrą i Nysą Łużycką, a na północy wybrzeżem od Rugii po Litwę. Granica ryska byłaby zmodyfikowana na korzyść Polski z powodu ludności polskiej w Inflantach Polskich, na Wołyniu, Podolu i Bukowinie. Odrzucała ideę imperialną, ponieważ opierała się na faktycznej bądź sugerowanej przemocy. Nawet polskie imperium zbudowane pokojowo mogłoby ulec pokusie egzekucji swoich decyzji siłą. Propaganda Niemiec i ZSRR pomawiała o imperializm Polskę, która zamierzała odzyskać swoje ziemie zabrane jej przez nich przemocą. „Pobudka” określała je rewindykacjonizmem ${ }^{88}$. Ubolewała, że polskie podziemie nie wypracowało konsensusu w sprawach organizacji Europy Środkowej. Idea federacyjna popierana przez socjalistów, syndykalistów, ludowców, demokratów i piłsudczyków zderzyła się z ideą imperialną obozów narodowego i katolickiego, jak inkorporacjonizmu i federacjonizmu w II Rzeczpospolitej. Mimo układu Beneš-Stalin „Pobudka” żądała od rządu propagowania idei federacyjnej ${ }^{89}$. W kwietniu 1944 r. zaproponowała, aby kraj i rząd wystąpiły z projektem konfederacji Europy Środkowej oraz powołały Komitety Białoruski i Ukraiński jako przyszłe rządy ${ }^{90}$. Konfederacja opierałaby się na równości państw i ścisłej współpracy politycznej, gospodarczej i wojskowej. Do końca wojny nawoływała do głoszenia idei jedności państw między Niemcami i ZSRR. Mniejszości słowiańskie i Litwini posiadałyby równe prawa z Polakami. Niemcy, Żydzi i Rosjanie musieli wyemigrować.

Organizacja Wojskowa „Wilki” uważała, że idea federacyjna była zbyt idealistyczna do realizacji w sytuacji geopolitycznej Polski ${ }^{91}$. Najpierw należało odzyskać niepodległość i historyczne granice od Odry po linię z 1772 r. (po Stalingradzie granica ryska) oraz dokonać szybkiego uprzemysłowienia. Dopiero jako Wielka Polska realizowałaby swoją tradycyjną misję unijną z sąsiednimi narodami, tworząc blok państw narodowych między Niemcami i ZSRR. OW „Wilki” sprzeciwiała się federalizacji Europy Środkowej i kontynentu. Polska miała w związku państw Europy Środkowej dominować, a nie być państwem zrównanym z małymi narodami. Nie przewidywała żadnych struktur ponadnarodowych, a prawa mniejszości narodowych uzależniała od ich postawy i interesu państwa polskiego, a nie od prawa międzynarodowego.

Polska Walcząca zbudowała sobie kapitał moralny, ale nie miała materialnego ${ }^{92}$. Działania dyplomatyczne i propaganda idei federacyjnej wobec zachodnich mocarstw i rządów emigracyjnych w Londynie nie wystarczyły do zjednoczenia Europy Środkowej. Nakaz ścisłej unii Europy Środkowej i idea forsownej industrializacji Polski były ze sobą organicznie powiązane, ponieważ współczesna technika, środki komunikacji i metody produkcji

\footnotetext{
88 Imperializm czy pacyfizm, „Pobudka”, styczeń 1942, nr 1, s. 19-21; Niezgoda narodowa, „Pobudka”, maj 1944, nr 1, s. 4-10.

89 AAN, DR, DIP, sygn. 202/III-86, Jak sadzić czeska politykę?, „Słowa Prawdy”, 15 luty 1944, nr 2, s. 42-43; Konfederacja a konsolidacja, „Pobudka”, maj 1944, nr 1, s. 19-21.

90 AAN, DR, DIP, sygn. 202/III-81, Polska $i$ Wschód, „Słowa Prawdy”, 7 IV 1944, nr 4, s. 98-99.

91 Propaganda a rzeczywistość, „Aktualne Wiadomości z Polski i ze Świata”, 1 VIII 1941, nr 31, s. 2; Wielka Polskę zbuduje Wielki Naród, AWPŚ, 24 X 1941, nr 43, s. 1; Przez odrodzenie narodu do wielkości, AWPŚ, 7 XI 1941, $\mathrm{nr}$ 45, s. 1-2; Konfederacja polsko-czeska, AWPŚ, 6 II 1942, nr 6, s. 4; Generat Sikorski o organizacji powojennej Europie, AWPŚ, 9 IV 1943, nr 11, s. 7; Sytuacja polityczna Polski, AWPŚ, 2 VII 1943, nr 24, s. 1.

${ }_{22}$ Sity dźwigajace, „Zryw”, 15 VI 1942, nr 4, s. 5-6; Wielki zryw narodowy, „Zryw”, 1 VIII 1942, nr 5, s. 4-7; Konstytucja czy plan pracy?, „Zryw”, 2 IX 1942, nr 8, s. 3-5; Mobilizacja przodownicka, „Zryw”, 25 X 1942, nr 10, s. 4-5; Przeciwnikom idei Zrywu Narodowego „Zryw”, 23 XI 1942, nr 11, s. 1-2.
} 
wymagały wielkiej przestrzeni. Najbliższą wspólnotę w Europie Środkowej tworzyły narody polski, czeski i słowacki, wynikającą z pokrewieństwa kulturowego, i litewski z racji pobratymstwa cywilizacyjnego i wspólnoty dziejów. Ten zespół narodów połączyłby się z bratnimi narodami słowiańskimi na południu. Blok państw Europy Środkowej na obszarze ABC dorównałby z czasem europejskim mocarstwom. Stałby się doniosłym czynnikiem w kształtowaniu Europy i świata. Polskie przyspieszenie gospodarcze prowadziło do zbudowania silnego państwa i zwiększenia solidarności narodowej. Potęga gospodarcza Polski wpływałaby na jej naturalną ,wielką przestrzeń” zachodniej Słowiańszczyzny i inne narody Europy Środkowej, i Południowej. Celem polskiej idei ich sfederowania było wyzwolenie i harmonizowanie ich sił twórczych. Jej zwycięstwo nadałoby głęboki sens ponoszonym przez nie wojennym ofiarom.

Stronnictwo Zrywu Narodowego popierało konfederację polsko-czechosłowacką ${ }^{93}$. Oba państwa umacniałyby kulturę słowiańską w zachodnim świecie. Ich rywalizacja doprowadziła do okupacji Europy Środkowej. Ich upadek pozwolił im odnaleźć drogę do współpracy dla dobra państw leżących między Niemcami i ZSRR. Podstawą wspólnej kultury było: bliskie pokrewieństwo plemienne, dziejowa wspólnota losów, wspólne warunki geopolityczne jako najdalej na zachód wysuniętych bastionów Słowiańszczyzny. Ich związek gwarantował im niepodległość, wzrost gospodarczy i bezpieczeństwo. Ruś Podkarpacka byłaby wolna w ramach unii środkowoeuropejskiej albo weszłaby do Polski, ale nie do Węgier. Dla dobra Słowiańszczyzny i współpracy polsko-czechosłowackiej E. Beneš powinien odejść z polityki. Na wschodzie Polska odzyskałaby granicę ryską. Na zachodzie doszłaby do Odry i Nysy Łużyckiej. Łużyce uzyskałyby niepodległość. Zgermanizowani Słowianie wróciliby do polskiej kultury. SZN nie negowało prawa Ukraińców i Białorusinów do niepodległości, ale sprzeciwiało się poświęcaniu polskiego potencjału w walce o ich państwa z ZSRR. Polską ekspansję widziało na obszarze ABC w celu budowy potęgi słowiańskiej razem z Czechosłowacją i Jugosławią. Podkreślało, że Litwini i Ukraińcy odrzucali ideę jagiellońską, zarzucając Polsce „kulturalny imperializm”. Bali się pokojowego przenikania kultur, co oznaczało ich słabość. Ich uczestnictwo w unii środkowoeuropejskiej było bardziej w ich interesie niż Polski ${ }^{94}$. Mniejszości słowiańskie w Polsce miałyby równe prawa z Polakami.

Ruch „Miecza i Pługa” uważał, że na endeckim nacjonalizmie i katolicyzmie Polska nie zbudowałaby związku państw Europy Środkowej. Odwoływał się do kultury i religii słowiańskiej, bo Imperium Słowiańskie miało być wspólnotą narodów słowiańskich ${ }^{95}$. Sojusznicze i wrogie mocarstwa traktowały Polskę jako państwo drugorzędne, dlatego swoją pozycję międzynarodową oparłaby na sile wypływającej z jedności narodów środkowoeuropejskich. Wielonarodowa i wieloreligijna Polska była za Jagiellonów mocarstwem, w którym pokojowo polonizowali się jej mieszkańcy. Wzorowane na jagiellońskim i brytyjskim Imperium Słowiańskie równoważyłoby potęgę i siłę Niemiec i ZSRR. Wpływałoby na realizację

\footnotetext{
93 Rozmowy Sikorski-Beně̌, „Zryw”, 15 VI 1942, nr 4, s. 6; Polska i Czechy, „Zryw”, 15 VI 1942, nr 4, s. 1-3; Wspólny Dom, „Zryw”, 1 I 1943, nr 13, s. 4-6; Dlaczego chcemy i musimy być demokratyczni, „Zryw”, 1 VI 1943, nr 23, s. 3; Węgry i dookoła Węgier, „Zryw”, 1 I 1943, nr 13, s. 2-6; Rocznica paktu polsko-czeskiego, „Zryw”, 1 II 1943, nr 15, s. 6.

94 Sprawy ukraińskie, „Zryw”, 10 V 1943, nr 21, s. 7-8; Rżnąć Lachów - cywilizacyjna idea Ukraińców, „Zryw”, 25 IX 1943, nr 27, s. 3-5; Sprawa Ziem Wschodnich, „Zryw”, 26 II 1944, nr 30-31, s. 4-5.

95 AAN, Ruch „Miecz i Pług”, sygn. 208/1, Deklaracja ideowa Ruchu Miecz i Pług, 1943, s. 3-4; Program Ruchu „Miecz i Pług”, s. 5-8; Synteza działalności politycznej Ruchu Miecz i Pług, „Miecz i Pług”, 1 IX 1943, nr 29, s. 2-5; Widmo zagłady małych narodów Europy Środkowej, „Wiadomości Codzienne”, 23 IV 1943, nr 94, s. 2.
} 
interesów Polski i państw regionu na arenie międzynarodowej. Struktura federacyjna nie gwarantowała wolności i szybkiego rozwoju państw członkowskich z racji podatności na wpływy mocarstw. Polski imperializm był reakcją obronną na niemiecki i radziecki. „MiP” nie zgadzał się z doktryną Dmowskiego, że lepiej było graniczyć z Rosją niż państwami narodów wschodnich ${ }^{6}$. Wielka Białoruś i Wielka Ukraina weszłyby do Imperium Słowiańskiego na zasadach unii z Polską. Następne byłyby państwa bałtyckie, Łużyce, Rumunia, Węgry, Jugosławia i Bułgaria. W ramach Imperium Słowiańskiego Polska odzyskałaby swoje historyczne ziemie zabrane jej przez Niemców i Rosjan. Z czasem wytworzyłby się naród słowiański. „MiP” uważał, że bez zasobów Polski, Czech i Ukrainy nie mogło ono powstać ${ }^{97}$. Układy polsko-czechosłowacki i jugosłowiańsko-grecki ułatwiały powołanie Imperium Słowiańskiego. Domagał się on od rządu poparcia niepodległości Białorusi i Ukrainy. Sprzeciwiał się federacji Europy w interesie Niemiec (Mitteleuropa, Paneuropa), ZSRR (radzieckie republiki) i Wielkiej Brytanii (Rada Europy) ${ }^{98}$. Za sojusz z ZSRR uznał E. Beneša i marszałka Josipa-Broz Tito za zdrajców Słowiańszczyzny.

Legion Unii Narodów Słowiańskich był za utworzeniem Bloku Państw Słowiańskich na czele z Polską i przyłączeniem do nich terytoriów zamieszkałych przez ludność słowiańską ${ }^{99}$. Dążył do zniesienia komunizmu w ZSRR. Po upadku dyktatur Włochy i Niemcy zostałyby poddane kontroli gospodarczej, a kolonie włoskie przekazane imperium słowiańskiemu. W Konfederacji Narodów Słowiańskich Polska zajęłaby dominującą pozycję nie przemocą, jak Niemcy i ZSRR, ale przez swoje zasługi wojenne, wyższość moralną i szybki rozwój gospodarczy. Program ideowo-polityczny LUNS kierował się na wzrost siły i potęgi Polski. Jej polityka wewnętrzna podporządkowałaby temu celowi rozwój gospodarczy i społeczny narodu. Wśród narodów słowiańskich miały powstawać narodowe Legiony o wspólnym podłożu ideologicznym, które posiadałyby autonomię narodowościową w ramach LUNS.

Jednoczesny atak dwóch sąsiednich mocarstw we wrześniu I939 r. w celu zniszczenia państwa i narodu polskiego skłonił obóz narodowy do wysunięcia idei imperialnej. Tylko Wielka Polska od Odry i Nysy Łużyckiej do Dźwiny, Bramy Smoleńskiej i Dniepru oraz zorganizowanie polskiego imperium na obszarze ABC dawało gwarancję niepodległości wszystkich państw środkowoeuropejskich oraz ich rozwój i bezpieczeństwo. Obóz narodowy odżegnywał się od kopiowania niemieckiego i radzieckiego imperializmu, co uzasadniał pokojowym i dobrowolnym jego tworzeniem. Zakładał, że doświadczenia narodów Europy Środkowej i Wschodniej z niemieckim i radzieckim terrorem sprzyjały polskim planom, a małe państwa zrozumiały, że nie mogły same się obronić. Przewidywał klęskę Niemiec i rozpad ZSRR w wyniku ich wojny. Idea imperialna konkurowała z koncepcją federacji środkowoeuropejskiej rządu oraz polskich ugrupowań socjalistycznych, syndykalistycznych, ludowych, piłsudczykowskich i demokratycznych w kraju i na emigracji. Obóz narodowy zwalczał ideę federacyjną, ponieważ: I) od epoki napoleońskiej i Kongresu Wiedeńskiego dominowała idea narodowa; 2) ograniczała suwerenność państwa narodowego; 3) groziła przekształceniem państwa narodowego w federację; 4) wprowadzała struktury ponadnarodowe, które

\footnotetext{
96 Jaki winien być polski nacjonalizm, „Miecz i Pług”, 5 VIII 1940, nr 16, s. 2-4.

97 Droga do wielkości wymaga wielkości, „Miecz i Pług”, 10 V 1942, nr 13, s. 8; Jedyna droga, „Miecz i Pług”, 7 XII 1942, nr 20, s. 4; BN, mf. 52214, Witaj Maj, Trzeci Maj, szczęściem płonie cały kraj, „Wiadomości Codzienne", 3 V 1943, nr 98, s. 1.

98 Przyszłość widziana oczami Churchilla, „Wiadomości Codzienne”, 23 III 1943, nr 67, s. 2.

99 AAN, LUNS, sygn. 211/4, Statut LUNS, s. 1; Instrukcja Prac Organizacyjnych, s. 2-4.
} 
zawłaszczały atrybuty państwa narodowego; 5) groziła dominacją europejskich mocarstw; 6) w federacji dochodziły do głosu międzynarodówki polityczne i gospodarczo-finansowe wrogie idei narodowej; 7) narzucała jednolity ustrój polityczny i społeczny; 8) propagowali ją przeciwnicy idei narodowej, narodu i państwa narodowego: socjaliści, liberałowie, demokraci, komuniści; 9) wzmacniała świadomość regionalną (Kaszubi, Ślązacy) i ponadnarodową (naród radziecki, europejski, słowiański); Io) wprowadzała równouprawnienie mniejszości narodowych; II) zagrażała państwom wielonarodowym, wywołując ich wrogość i zbrojne reakcje; I2) przewidywała dobrowolność i równość małych i dużych państw w federacji; I3) była wroga idei imperialnej; I4) rozbijała historyczne terytoria państw i narody, jak to robili Rosjanie, Niemcy i polscy federaliści, wspierając separatyzm litewski, białoruski i ukraiński, niszczący historyczny naród polski od unii lubelskiej.

W czasie II wojny światowej reakcją na radziecki i niemiecki imperializm były w polskiej myśli politycznej dwie odmienne geopolityczne koncepcje federacji środkowoeuropejskiej i polskiego imperium. Obie zakładały klęskę Niemiec i rozpad ZSRR. Zagrożone ich imperializmem Państwa i narody Europy Środkowej i Wschodniej miały zgrupować się wokół Polski. Ich główną różnicą była forma i ustrój obu tych geopolitycznych podmiotów. Obóz narodowy głosił ideę imperialną, ponieważ tylko tak widział zachowanie niezależności Europy Środkowej od Niemiec i ZSRR oraz odbudowę silnego, narodowego i suwerennego państwa polskiego.

\section{The national camp to the concept of federation during the Second World War Summary}

During World War II, the national camp preached the idea of imperialism in Central Europe. Built peacefully, the Polish empire was supposed to protect the independence and security of countries in Central Europe against Germany and the Soviet Union, and thus got the title 'the Great Poland'. As part of the empire, nation-states were retined. The National camp was opposed to the idea of the Federation, promoted by the government-in-exile. For the 'National camp' idea of federation in the regional, European and global level was an anachronism. Post-war international cooperation was based on nation-states and their alliances.

Keywords: World War II, the national camp, Fighting Poland, Polish idea of federation, Polish idea of imperial, Polish political thought in the 2oth century

Nota o Autorze: Dr Dariusz Miszewski, historyk, absolwent Uniwersytetu Wrocławskiego, adiunkt w Zakładzie Stosunków Międzynarodowych Instytutu Politologii Uniwersytetu Zielonogórskiego (I999-20I3), od 2016 adiunkt na Wydziale Bezpieczeństwa Narodowego Akademii Sztuki Wojennej, specjalizacja stosunki polsko-czesko-słowackie XX-XXI w., mniejszości narodowe w Europie Środkowej i polska myśl polityczna XX w. 